it is not hard to discern the origin of that bias. Unquestionably, as Batchen points out, much of it stems from the German Romantics, particularly Caspar David Friedrich (whose Wanderer Above the Sea of Fog was, appropriately, Fontcuberta's first victim). But the form that this aesthetic takes in Terragen's creations is most clearly reminiscent of the American Romantics such as Thomas Cole (who was deeply influenced by Alexander von Humboldt's descriptions of the Andes) and his student Frederic Edwin Church. For generations of Americans, Church's heightened (in all senses) landscapes were the way nature 'really' looked. That influence is clear in the planetary paintings that pre-date the current computergenerated versions, as well as in the vistas seen in any 'space opera' Hollywood movie.

But the influence of such artistic traditions on scientific imagery does not stop at real landscapes. Stock representations of the Sublime can also be discerned in company photographs of chemical plants soaring like tubular mountain ranges into coppery skies, and in the 'atomic landscapes' that can now be constructed from scanning probe microscopy. Even the

\section{Taking flight}

\author{
Birds of South Asia: The Ripley Guide \\ by Pamela C. Rasmussen \& John C. Anderton \\ Smithsonian Institution/Lynx Edicions: 2005. \\ Two volumes, 384 and 688 pp. $€ 55$
}

\section{Richard Grimmett}

S. Dillon Ripley is a titan of twentieth-century Indian ornithology, having written three major works: Synopsis of the Birds of India and Pakistan (Bombay Natural History Society, 1961), the ten-volume Handbook of the Birds of India and Pakistan (Oxford University Press, 1968-98), and A Pictorial Guide to Birds of the Indian Subcontinent (Oxford University Press, 1983), the last two in collaboration with Indian ornithologist Salim Ali. As secretary emeritus at the Smithsonian Institution, Ripley initiated a new bird guide for the Indian subcontinent, intended as his final major work on the region. To his credit, he engaged Pamela Rasmussen and John Anderton to work on the task. Ripley was taken ill shortly afterwards and died in 2001. But the project lived on and the longawaited result has now been published.

The two-volume Birds of South Asia: The Ripley Guide covers the avifauna of the entire Indian subcontinent and includes 1,441 species. It expands on similar work by including Afghanistan and the Chagos Archipelago. Volume 1: Field Guide is portable and comprises 180 colour plates by John Anderton and other renowned bird illustrators, with brief adjacent text on field identification and distribution maps. The plates are generally good to excellent, with comprehensive coverage of plumage, although the illustrations of a few birds, such as the common nightingale, have suffered from an over-reliance on museum specimens rather than observations in the field. Several recently described species have been illustrated in a field guide for the first time here. Volume 2: Attributes and Status is a dense, comprehensive work that contains masses of new information on bird identification, variation, occurrence, habits, vocalizations and taxonomy.

The book's greatest value is that Rasmussen has taken nothing for granted, even informa- tion published in Ripley's own works. Everything from bird distributions, measurements, vocalizations and identification features has been reviewed from scratch. The species list for the region has also been completely revised. Quite a few species are conservatively listed as 'hypothetical', with many previously published and significant records being regarded as 'insufficiently proven' (to the disappointment, no doubt, of many a living birdwatcher). Two well respected ornithologists from the first half of the twentieth century, E. C. Stuart Baker and Richard Meinertzhagen, are taken to task for their carelessness or fraudulent work (see Nature 437, 302-303; 2005). Their records - which underpinned Ripley's previous books on the subcontinent - are either treated with caution or dismissed. Most significantly, and bravely, Rasmussen has given full species status to many forms for the first time in any modern guide. The common blackbird, for example, is treated as three species, with the Himalayan and south Indian forms elevated to full species. On this interpretation of the periodic table recently produced by Britain's Royal Society of Chemistry, with its crags thrusting out of a placid lake, has a Terragenic air.

More than 40 years ago, art historian Ernst Gombrich pointed out in his seminal book Art and Illusion (Pantheon, 1960) that no human depiction of the world (and this surely now includes photography) escapes our culturally acquired stereotyping. Maybe Fontcuberta's book will serve to remind scientists that the same applies to them too.

Philip Ball is a consultant editor for Nature.

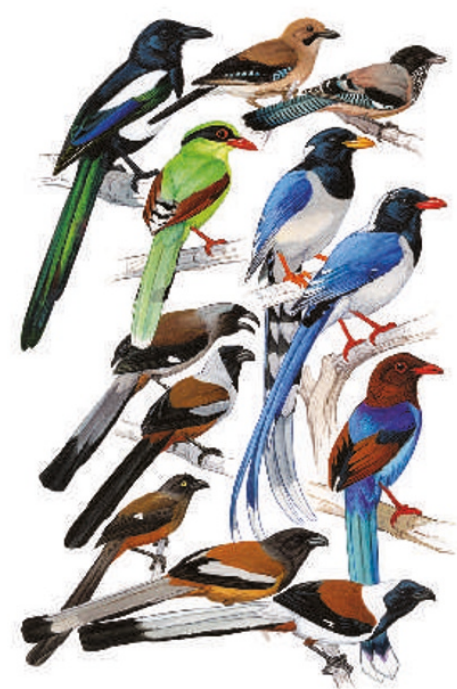

Bird identification on a plate: magpies, jays and treepies, as illustrated in Birds of South Asia.

she is almost certainly correct, although readers will have to wait for further justification in the scientific literature before her judgements can be fully assessed.

Richard Grimmett is at BirdLife International Asia Division, Toyo-Shinjuku Building 2F, 1-12-15 Shinjuku, Tokyo 160-0022, Japan.

\title{
Tracing the history of art
}

\section{Optics, Instruments and Painting, 1420-1720: Reflections on the Hockney-Falco Thesis [Early Science and Medicine Vol. 10 no. 2] edited by Sven Dupré \\ Brill Academic: 2005. 214 pp. $\$ 74$}

\section{David G. Stork}

Readers of Nature were among the first to learn of an intriguing theory proposed by artist David Hockney. He suggested that as early as 1420 some leading European artists used concave mirrors to project optical images on to their canvases, and traced them during the execution of their paintings (see Nature 400, 524 (1999); 412, 860 (2001); 417, 794 (2002)). The claim is sometimes called the Hockney-Falco thesis to acknowledge the technical efforts of physicist Charles Falco. Hockney thinks the procedure was a key source of the naturalism, or 'optical look', arising in early Renaissance painting.

This special issue of Early Science and Medicine is a product of a four-day symposium in Ghent in November 2003. It is the first work to provide independent evidence on the material culture and documentary record, and analyses of optical knowledge, of the fifteenth century.

Did artists or scientists have access to suitable mirrors? Sara Schechner, curator of historical instruments at Harvard University, explores the state of optical fabrication at the time. She concludes that "Renaissance mirrors were far from offering the painter a short-cut to a detailed and naturalistic image of his subject." Early mirrors, she argues, "could not reflect or project clear, undistorted, 'photo-realistic' images, as Hockney and Falco suggest." 
Renaissance art historian Yvonne Yiu of the University of Basel finds no surviving textual evidence for the procedure: "the silence of this considerable body of texts on the concave mirror projection method is deafening." To Yiu it seems inconceivable that "well-informed contemporaries" would not have described a method that, according to Hockney and Falco, "revolutionized the art of their time". Filippo Camerota, a historian of Renaissance scientific instruments at the Istituto e Museo di Storia della Scienza in Florence, points out that in the second half of the sixteenth century, when appropriate projections were first documented, Giambattista della Porta wrote: "If you are incapable of painting a portrait, this is a method you should know." This is hardly support for the claim that tracing projections sparked a revolution in painting more than a century earlier.

The scientist Witelo's Perspectiva, from about 1270 , has previously been used as evidence that Renaissance scientists and possibly artists knew about appropriate projections. But Mark Smith, a historian of Medieval and Renaissance optics at the University of Missouri, provides an object lesson in the importance of expert knowledge when judging such a claim. Hockney and Falco take Witelo as saying that the image literally floats in space or is somehow projected to a location outside the mirror. "What Witelo really means," says Smith, "is that the image will be located behind the reflecting surface”. The public might have concluded that Witelo was describing a projection of a real image and hence is closely related to Hockney's method. A student of basic optics might have concluded that Witelo described a real image in space, not on a screen, and hence only distantly related to Hockney's method. But after analysing the Latin text, context and contemporary thinking, Smith argues that Witelo was describing instead a virtual image, unrelated to Hockney's method.

It seems that Hockney has recently retreated from his claim that artists actually traced projected images to a weaker view that artists merely saw and were influenced by such images. Philosopher of science Christoph Lüthy of the Radboud University of Nijmegen has read contemporary texts and concludes the former claim is "fairly implausible" and the latter "still awaits corroborating evidence".

The volume's editor, Sven Dupré, a historian of Renaissance optics, summarizes the conclusions of the contributors. It makes the Hockney-Falco theory "extremely unlikely as far as its application for the period before the first textual reference to image projection around 1550 is concerned", he writes.

This well-written volume may close the door on the Hockney-Falco tracing thesis. But it should also prove a good resource, especially for optical scientists lacking a background in the history of art or science, from which to explore optics in the early Renaissance.

David G. Stork is chief scientist at Ricoh

Innovations, Menlo Park, California 94028, USA.

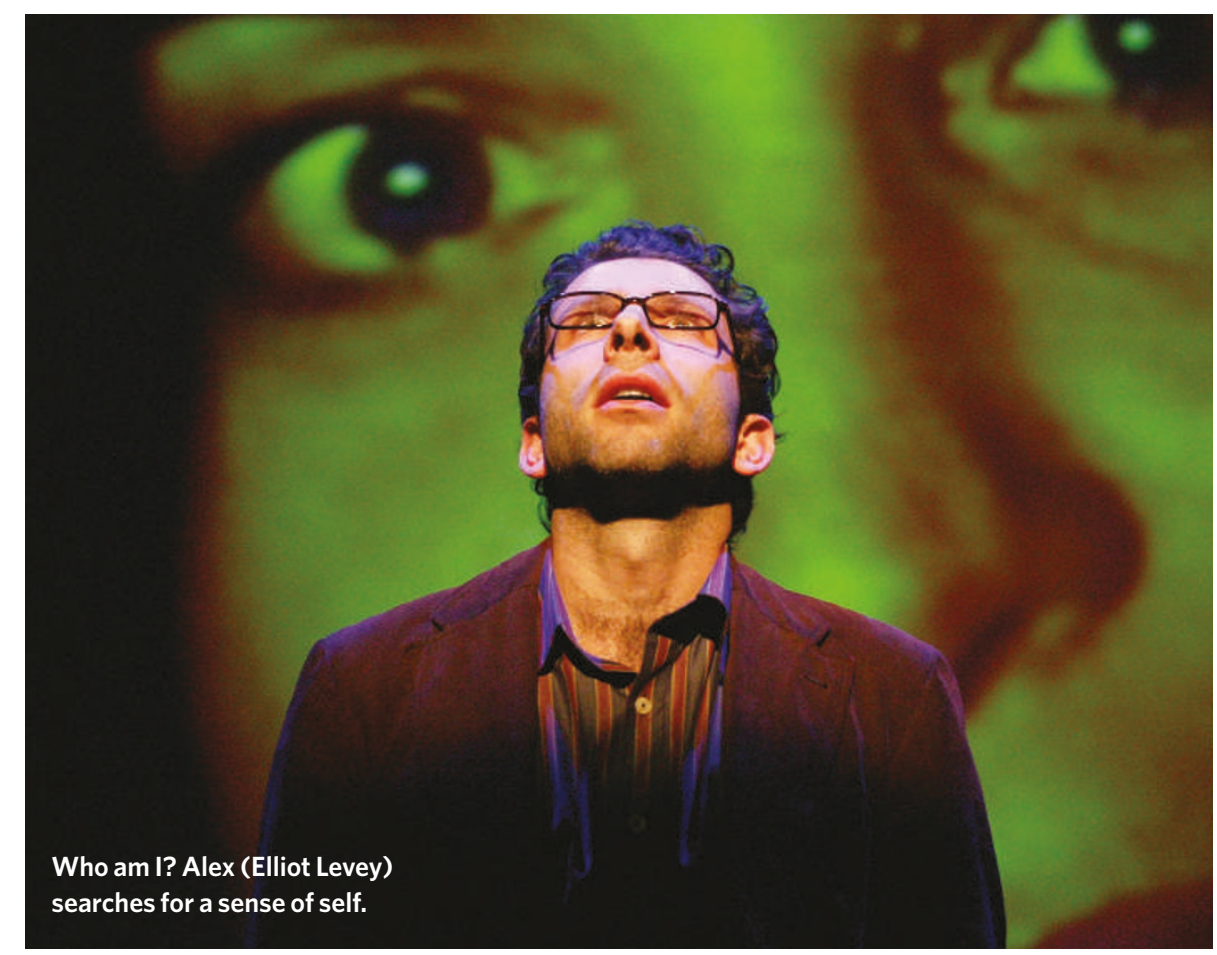

THEATRE

\section{Self deception}

\section{On Ego}

Soho Theatre in London, UK,

until 7 January 2006.

\section{Lucy Odling-Smee}

What is this phenomenon that we call our sense of self? Is it the secular equivalent of the soul? Or is it just loops of wiring within the wet, grey stuff of our brains? Inspired by neuropsychologist Paul Broks' book Into the Silent Land (Atlantic, 2003), theatre director Mick Gordon examines this dilemma in his new play On Ego.

The play opens with a lecture by a neurologist, Alex, who explains why the mass of neurons behind the face annihilates the myth of the soul. Equipped with slides of scalpels probing brain tissue, and a dripping human brain lifted from a bucket, he argues that the self is no more than an aggregate of an individual's thoughts, feelings, perceptions and actions.

To make his point - that the 'I' is an illusion, and that we are no more than bundles of information - Alex enters a teleportation machine that vaporizes his physical body. The procedure involves scanning every atom of his body and transmitting the information by radio waves to a new destination. It should automatically eliminate the original Alex, but it goes wrong, leaving two versions, who immediately start acquiring different experiences and memories. When faced with the prospect of being eradicated, however, his original 'self' resists and an intuitive sense that he is an 'I' after all kicks in with a vengeance.

Meanwhile, the duplicate Alex is unaware of his status and carries on as normal. But as the play proceeds he finds himself rejected by his wife, Alice, who is struck down with the psychological disorder Capgras' syndrome a condition that makes her believe that her husband is an impostor.

Physical duplication dances with illusion and delusion. Just as Alice's perception of Alex changes, so does his perception of himself. The original Alex is confronted with two polar views of himself: his objective scientific view and his subjective view as he reacts to his experiences.

The many layers of the play, which stretches from the fantastical to a chilling portrayal of lives blighted by brain disease, is saved from chaos by being anchored to a carefully thoughtout philosophical discussion about the nature of the self. While Alice struggles with her loss of self through lost love, her husband - and the audience - are left contemplating the space between what we rationally think we are and what we intuitively believe ourselves to be.

The stripping back of illusions to reveal the true self has long been the fodder of dramatists - think of King Lear peeling off his robes in the wind and the rain to reveal the "bare, forked animal" beneath. But in pushing against the boundaries of science, Gordon creates a tale that is both disturbing and curiously liberating. Perhaps we will never succeed in scientifically stripping back the intuitive sense of self, and perhaps, as Broks says, this is the "beautiful paradox" of being a human trying to understand itself.

Lucy Odling-Smee is a subeditor for Nature. 